\title{
IDENTIFICATION OF DANGER ZONES FOR SURFACE WATER USING GIS (SIP) - MAPINFO SYSTEM ON AN EXAMPLE OF UPPER NAREW RIVER CATCHMENT
}

\author{
Mirosław Skorbiłowicz' ${ }^{1}$ Elżbieta Skorbiłowicz' \\ 1 Bialystok University of Technology, Wiejska 45A, 15-351 Bialystok, Poland, e-mail: m.skorbilowicz@pb.edu.pl
}

Received: 2016.03.16

Accepted: 2016.06.01

Published: 2016.07.01

\begin{abstract}
Creating the buffer zones is a function intended to designate an area in particular, of a constant distance around the spatial objects. The aim of the study was to create maps as thematic layers, which served to identify areas of existing and potential contamination of surface water and other environmental elements. Among others, it made possible to localize the areas potentially affected by the surface water pollution due to transport; localize the areas potentially affected by the surface water pollution due to the discharge of sewage from human settlements; localize the zones with mitigated impact of communication emissions due to the natural protection of forests taking the form of so-called geochemical barriers. The spatial analyzes allowed to generate model-zones of the existing and potential threat of water pollution in the Narew river catchment. Designated danger zones can be verified by studies as well as they can be very helpful in determining the monitoring network and for water quality modeling process.
\end{abstract}

Keywords: GIS, danger zones, river, buffer zone.

\section{INTRODUCTION}

Spatial Information System (SIP), Geographic Information System (GIS), and Land Information System are used interchangeably in most publications. The SIP involves the process of acquiring, processing and publication of data related to spatial characteristics of objects (Izdebski 2008). Currently, methods of GIS are appreciated and widely used around the world because of great opportunities and easy access for their use. They are used in various kinds of research related to the protection and shaping the environment (Helis and Górecki 2013, Klimczak and Galant 2009, Nowicka and all 2014, Stabłoń and all 2015, Nowicka and all 2015). The use of geometric features of software referring to SIP can be very useful for spatial analysis of interesting phenomena, e.g. assessment of specific objects distribution. One of the applications is to buffer vector data; it is designation of areas within a cer- tain distance from elements of a particular layer: points, lines, polygons (Gliński 2010). The threat of the natural environment, including the aquatic, due to anthropogenic influences can be analyzed on the basis of the so-called buffer options. Group of the neighborhood analysis is based mainly on creating the buffers around spatial objects (points, lines, polygons) and aims at setting a specified radius area surrounding a particular object. Determination of the buffer area is used to identify objects within a certain distance from the object having the harmful impact on the environment and to determine what objects can be exposed in a hypothetical zone of influence (Poławski 1998). The process of cartographic modeling can use a spectrum of analytical functions. Myrda (1997) applied software Maplnfo to incorporate the assumptions of cartographic modeling. His choice resulted from great analytical and utility opportunities of desktop GIS-type package. Benefits of GIS software is also confirmed by the large num- 
ber of users. Creating the buffer zones is a function intended to designate an area in particular, constant distance around the spatial objects.

The aim of the study was to create maps being the thematic layers, which served to identify areas of existing and potential contamination of surface water and other environmental elements. Among others, it made possible to:

- localize the areas potentially affected by the surface water pollution due to transport;

- localize the areas potentially affected by the surface water pollution due to the discharge of sewage from human settlements;

- localize the zones with mitigated impact of communication emissions due to the natural protection of forests taking a form of a socalled geochemical barriers;

- localize the zones of mitigated impact of various pollutants to waterways by natural protecting of forests;

- localize the zones within surface waters potentially threatened by pollution from agricultural sources.

\section{METHODS}

In spatial analysis, the buffer is most often determined the polygon surrounding a given object or a group of objects. It is defined by specifying the distance (limit values) of its stroke from the stroke of other objects. The point and linear objects can be buffered from the outside, while buffers of polygons can be created on both the external and internal side (Urbański 2012).

Zemanek et al. (2009) created a buffer zone of 150 meters from the main and local roads in the analyzed municipality. For items such as: a strip of land along the railway routes and stations, the investigators have designated the protection zones (buffers) of 50 meters wide.

Map of buffers on traffic and rail routes show the extent of the impact of transport pollution on lands adjacent to these roads. Imposing the buffers on the network of streams aimed at isolating the protection zones. The idea of protection zones consists in that such a buffer is determined along the stream, within which any contamination poses a particular threat to water quality. Watercourses were divided into three classes, which have been given some weight depending on their size. Narew River is the watercourse with the highest weight, while Orlanka river received an average weight, and other watercourses got the lowest weight. The adopted classification stems from the fact that the larger watercourse, the more environmental damage is entailed due to its pollution. The largest watercourse (the Narew river) was overlapped with the buffer of 120 meter width, the average ones (e.g. the Orlanka river) - 60 meter wide buffer, whilst the small watercourses buffer of 40 meters width. It was accepted that road had buffers of 300 meter width.

Numerical implementation of GIS work was carried out in two phases.

The first phase consisted of the introduction of data using GIS MapInfo software version 4.1 for Windows. Data was collected from manual digitization of raster obtained by scanning a paper map on the monitor screen. The data source was the topographic map at a scale of 1: 200,000. As a result of digitization, the following thematic layers were created: watercourses, roads and railways, rivers, forests, fields and grasslands, buffers, as well as villages.

The second phase - data analysis aimed at the localization of places where surface waters become contaminated.

Localization of areas potentially influencing the surface water pollution from roads was created when the zones of threat due to transport were put onto the thematic layer of the watercourses network map. The map helped to localize sections of watercourses under the influence of pollution from roads. These are pollutants that enter the water by falling the dust on the water surface. These contaminants are also settled on the ground during rainfall along with the surface or subsurface runoff and get into the flowing waters.

Localization of areas potentially affecting the surface water pollution by discharge of sewage from human settlements is the result of the imposition of the boundaries of the built environment on the protective zoning map (buffers) along watercourses. Adverse effects of settlements on the watercourse is greater the closer watercourse they are located, while the largest, when they are situated within the protective buffer of the river.

Localization of zones with mitigated impact of transport emissions due to the natural protection of forests was created by combining the forested area with road buffers (dangers). It was assumed that forests provide a protection against transport pollution through absorption of their large load, and thus there is a possibility to localize the areas where less intense effects can be expected. 
Localization of zones with mitigated impact of pollution on watercourses due to natural forests protecting was created by overlapping the map showing the area of milder emissions from road onto the map of protection zones (buffer) along watercourses. The aim of the operation will be to verify whether forests actually have the limiting effect on water pollution.

Localization of areas potentially threatened by area-based pollution (among others, increased supply of nitrogen and phosphorus) from agricultural fields and grasslands was made after the imposition of watercourse network buffer layers onto the layer with grasslands and fields as well as layers of towns (villages).

During the process of computer analysis, there is a possibility to make more models. In this case, the limitation occurred due to the nature and possibilities of computer printout that is not able to convey so much information as direct computer analysis.

After completing the necessary models, format of their output files was changed from MapInfo into jpeg to facilitate their transfer and printing on different computer platforms and systems. For this purpose, graphics software Micrografx Picture Publisher was alternatively used.

\section{RESULTS}

A detailed distribution of predicted water pollution zones of upper Narew river catchment was shown in the following models (Figures 1-20). Due to the high level of details, magnification of separate areas for the same models were made to present the most important localizations of the analyzed zones.

Figures 1 and 2 show the localization of model zones of watercourse pollution risk from roads. Model zones were developed after imposition of the buffer layer (fixed distances illustrating the extent of contamination - $200 \mathrm{~m}$ from the road edges on both sides) on the model layer of watercourses. Common areas of buffers and watercourses are a potential communication danger for the upper Narew river. Figure 3 shows one of the zones, in which buffers imposed on the roads (scope of probable pollution) that have points in common with watercourses in the area, are visible. At these points along the river Sections of approximately $400 \mathrm{~m}$ long were formed, where river pollution can be predicted, were created at these points along the river. At point 5, there are 2 buffers next to each other forming a total of $800 \mathrm{~m}$ danger zone, which is the sum of the two communication routes interaction. Figures 1 and 2 present places where there are crossroads of many tracts resulting in a sum of their adverse effects. At these points, as well as other ones that are within the communication pollution range, it is particularly recommended to monitor the bottom sediments of rivers, which are located in the areas of risks posed by both car and train transport.

Figures 4, 5, 6, 7, 8, and 9 illustrate models, in which buffer zone layer (protective) of rivers overlapped with the layer of constant distances from settlement units being general risk zones due to human settlements. Combination of these models gave the resulting model on which the danger zones of the upper Narew rivers due to human settlements (villages and towns) can be localized. These zones should be under a constant control of environmental services. Protective buffer along Biała river (Figure 6) and melioration ditch Lubka was imposed on the zone of Bielsk

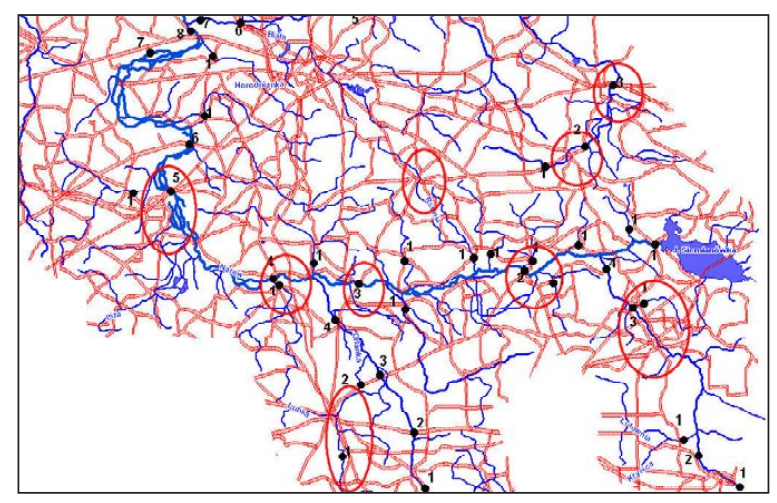

Figure 1. Localization of zones vulnerable to surface water pollution due to transport.

$\longrightarrow$ - danger zone, red lines - buffers of roads.

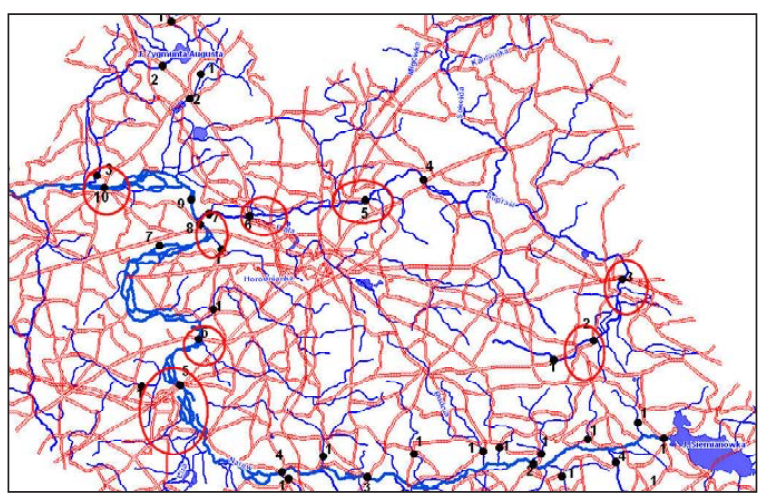

Figure 2. Localization of zones vulnerable to surface water pollution due to transport. - danger zone, red lines - buffers of roads. 


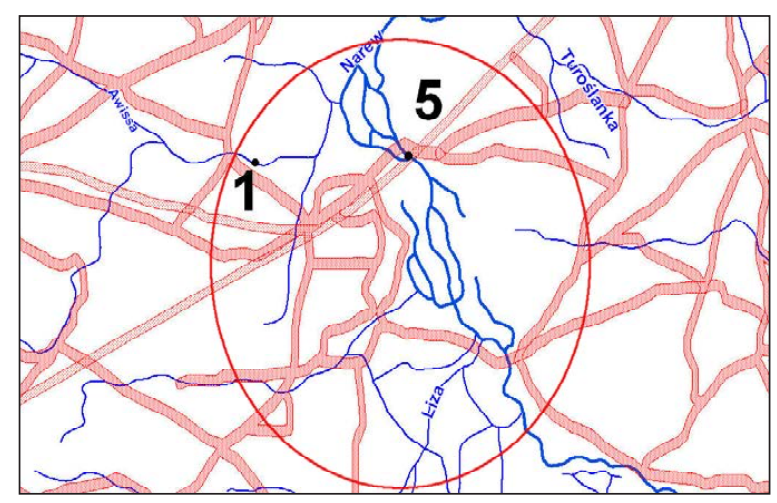

Figure 3. Localization of zones vulnerable to surface water pollution due to transport (neighborhood of Narew and Awissa rivers) $\longrightarrow$ - danger zone, red lines - buffers of roads.

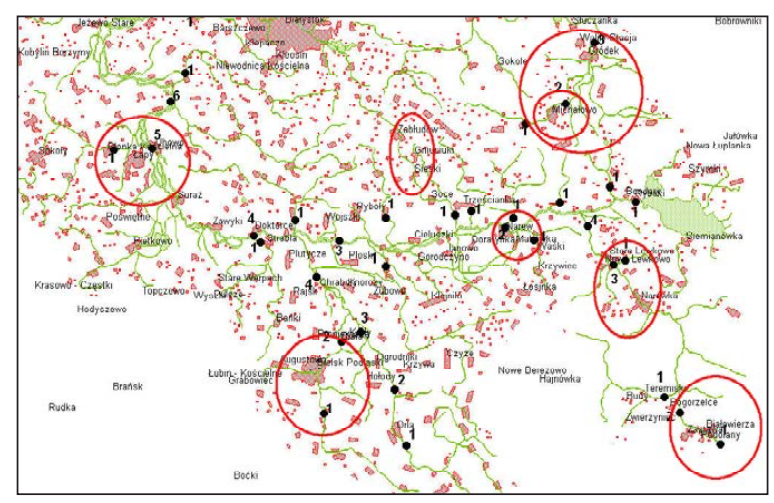

Figure 4. Localization of zones vulnerable to surface water pollution due to sewage from human settlements.

$\longrightarrow$ - danger zone, green line - protection buffer of watercourses, red figures - settlement units

Podlaski town interaction. In addition, this model (Figure 6) allows to read the length of section subjected to possible contamination. Figures 7, 8, and 9 present risk zones for Supraśl river due to Michałowo and Gródek as well as due to Łapy town for Awissa river and Uhowo for Narew river. The model-buffer threat zones from human settlements are directly superimposed on the protection zones of watercourses Supraśl, Awissa, and Narew allowing e.g. determination of control points in the process of river waters monitoring and conducting the technical activities upon water protection.

Model figures 10, 11, 12, and 13 present the zones of mitigated transport impact on rivers due to natural protection of forests and other biogeochemical barriers. These zones were created after the imposition of potential contamination zones model (buffer of $400 \mathrm{~m}$ width) from the transport on a thematic model-layer of forests and shrubs. Combination of the buffer layer

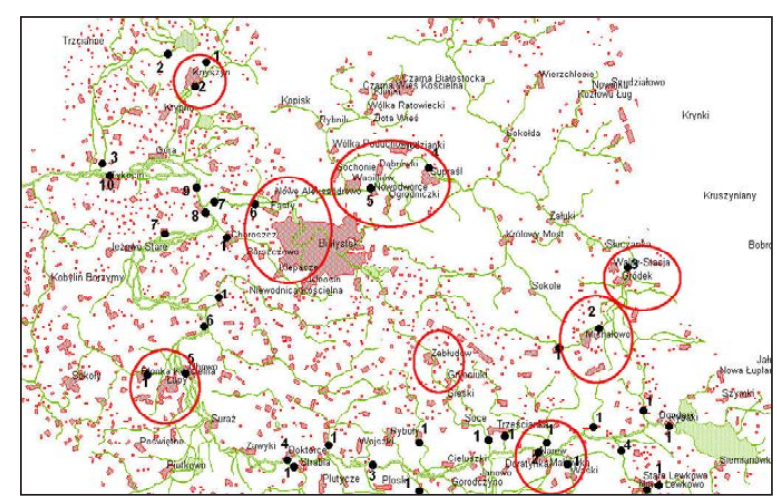

Figure 5. Localization of zones vulnerable to surface water pollution due to sewage from human settlements.

danger zone, green line - protection buffer of watercourses, red figures - settlement units

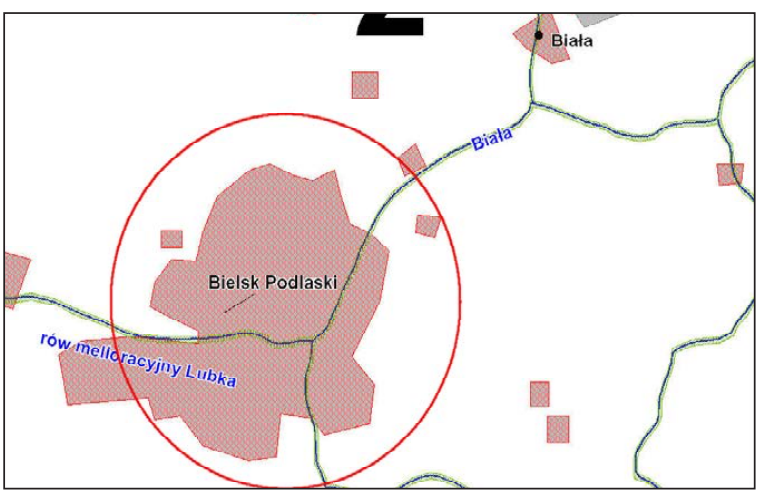

Figure 6. Localization of zones vulnerable to surface water pollution due to sewage from Bielsk Podlaski. $\longrightarrow$ - danger zone, green line - protection buffer of watercourses, red figures - settlement units

with the forest layer gave the resulting model on the base of which the opportunity to designate zones with softened impact of transport pollution to watercourses and streams within the catchment was created. Part of road buffers in some sections are overlapped with forest areas, which almost completely isolate these fragments from their negative effect not only on watercourses, but also on the soils. In addition to the marked zones, there are many others that can be read from these models, but directly on the computer screen. Printing capabilities in this regard are strongly limited. Figure 12 shows the magnified example of such zone type. Section of Narew river is subject to quite limited influence of the transport because of the isolation of threat buffer-zones by forest areas. Similar situation can be observed in model No 13, where part of road sections run within forest boundaries that in some fragments form the protection zones for watercourses and soils. 


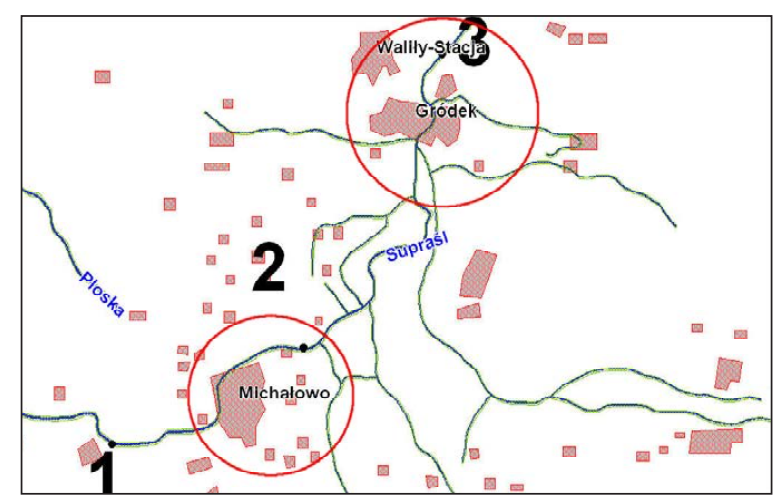

Figure 7. Localization of zones vulnerable to surface water pollution due to sewage from Michałowo and Gródek.

$\longrightarrow$ - danger zone, green line - protection buffer of watercourses, red figures - settlement units

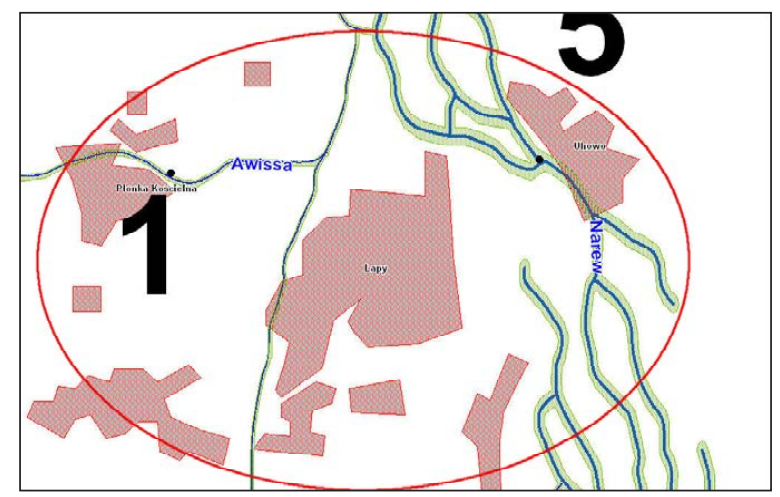

Figure 8. Localization of zones vulnerable to surface water pollution due to sewage from Łapy and Uhowo.

$\longrightarrow$ - danger zone, green line - protection buffer of watercourses, red figures - settlement units

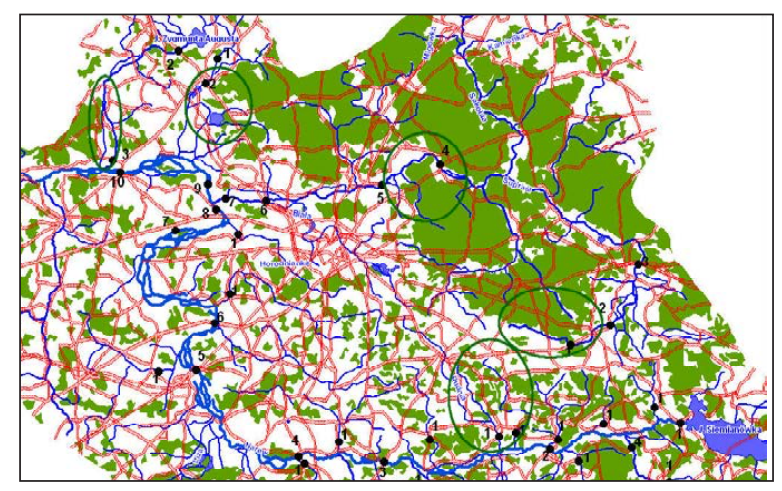

Figure 11. Localization of zones with mitigated impact on rivers due to natural forest protection and other geochemical barriers.

$\longrightarrow$ - protection zone, green shape - forest, red lines - buffers of roads

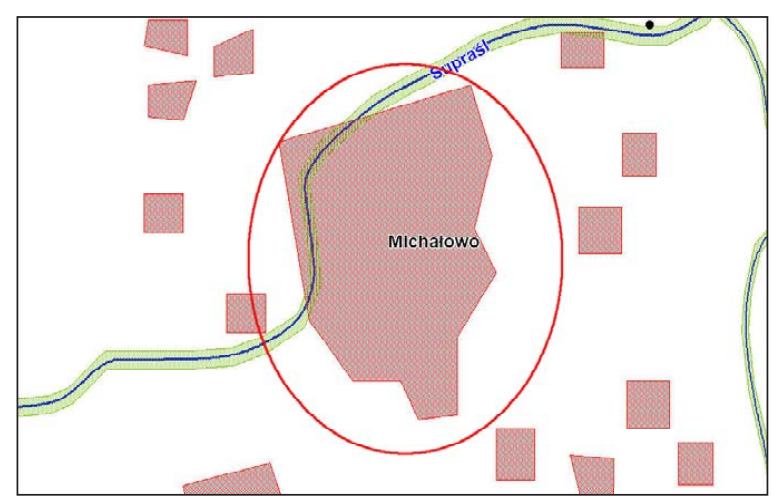

Figure 9. Localization of zones vulnerable to surface water pollution due to sewage from Michałowo. - danger zone, green line - protection buffer of watercourses, red figures - settlement units

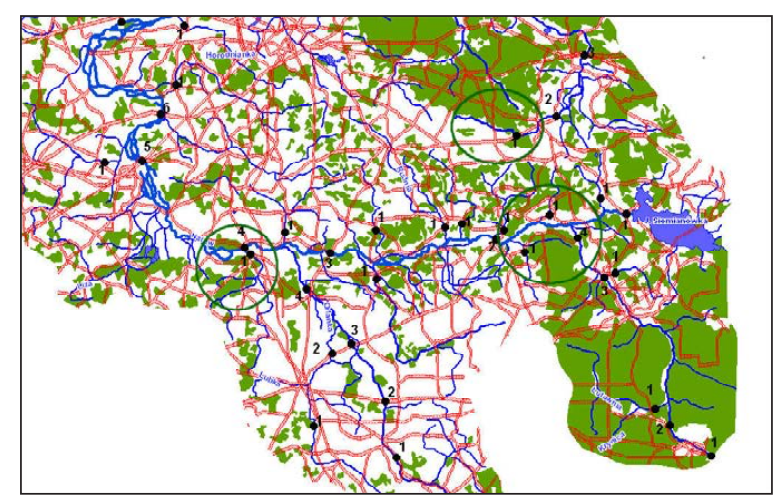

Figure 10. Localization of zones with mitigated impact on rivers due to natural forest protection and other geochemical barriers.

- protection zone, green shape - forest, red lines - buffers of roads

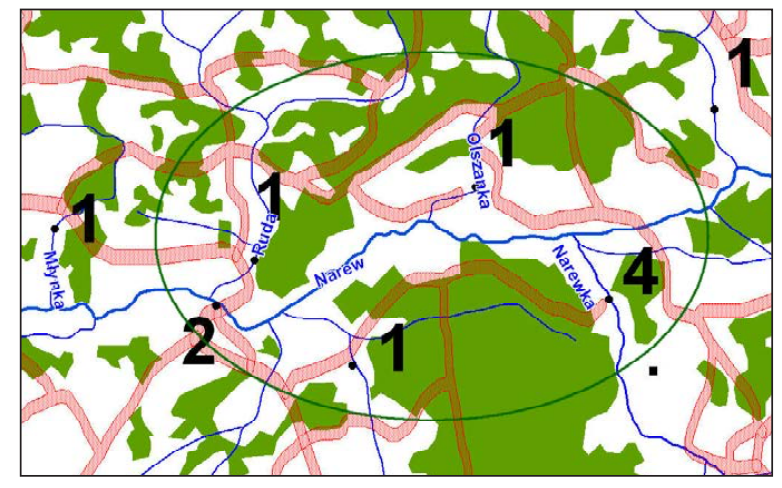

Figure 12. Localization of zones with mitigated impact on rivers due to natural forest protection. - protection zone, green shape - forest, red lines - buffers of roads 
Figures 14, 15, 16, and 17 illustrate the results of modeling the water threat zones localization of the upper Narew river area with nitrogen and phosphorus compounds. The zones delimited in Figure 14 include areas adjacent to rivers $\mathrm{Na}$ rew, Łoknica, and Czarna. These areas and others presented in the subsequent figures were created by combining the buffer-protection zones of rivers with grasslands and fields areas. Tangential or overlapping areas gave the resulting models, which are specific zones of danger for surface waters. Designated model threat zones shown in Figure 14 , especially meadows and pastures in the upper Narew river catchment area form a regular zone-band separating the watercourses from the other forms of terrain, including fields. They form a kind of protective zone for watercourses in the Narew river valley, decisively affecting the low levels of e.g. nitrate nitrogen in Narew river water and other watercourses. Figure 15 shows greater

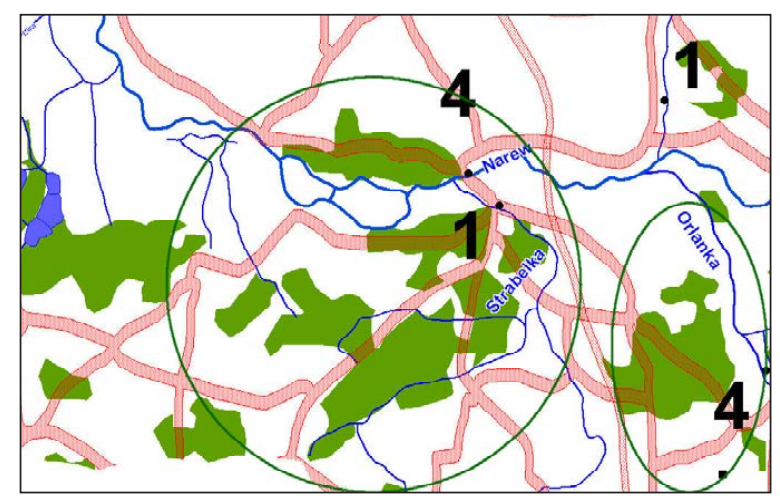

Figure 13. Localization of zones with mitigated impact on rivers due to natural forest protection.
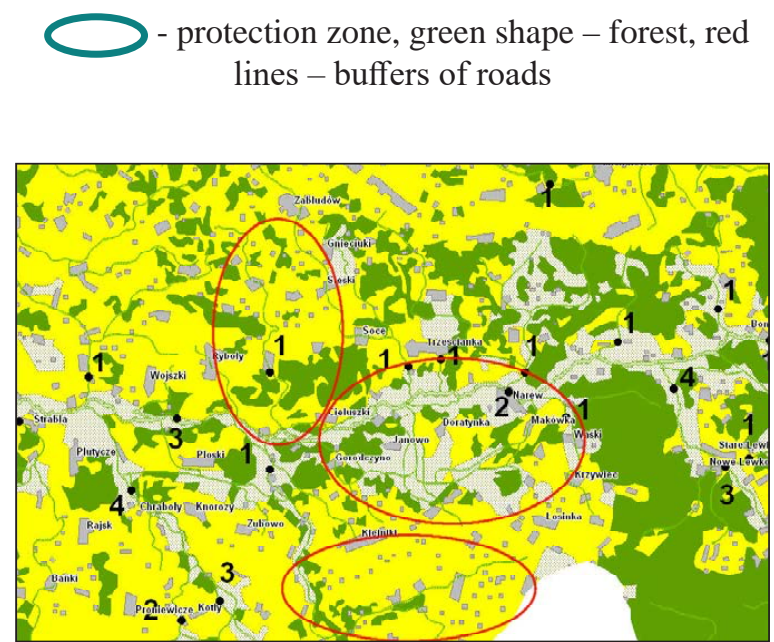

Figure 14. Localization of zones potentially threatened by nitrogen and phosphorus penetration into surface water from the fields and grasslands.

$\longrightarrow$ - danger zone, yellow shape - fields, green dotted shape - grassland, green shape - forest number of designated zones of threats due to nitrogen and phosphorus from fields. These zones, among others, cover the neighborhood of an initial fragment of the Suprasl river. The analyzed areas are dominated by agriculture with meadows and pastures. The Suprasl river protection zones are exposed to the impact of these areas. Figure 16 presents designated zones-models, that cover The Narew National Park, which is likely to be exposed to the impact of surrounding fields and pastures. Figure 17 illustrates the zones of nitrogen and phosphorus supply risk for the Orlanka river. These zones include typically agricultural areas that cover almost all protection-buffer surface of Orlanka river. Figures 18, 19, and 20 present models of grasslands distribution along Narew river. The grasslands often play the role of pastures. Therefore, the area can be considered a direct threat zone, among others, due to ammonia supply into rivers, around which they are localized.

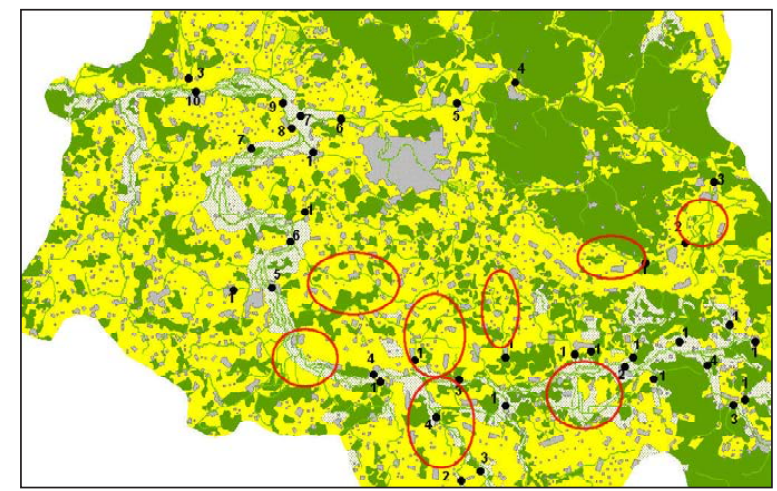

Figure 15. Localization of zones potentially threatened by nitrogen and phosphorus penetration into surface water from the fields and grasslands - danger zone, yellow shape - fields, green dotted shape - grassland, green shape - forest

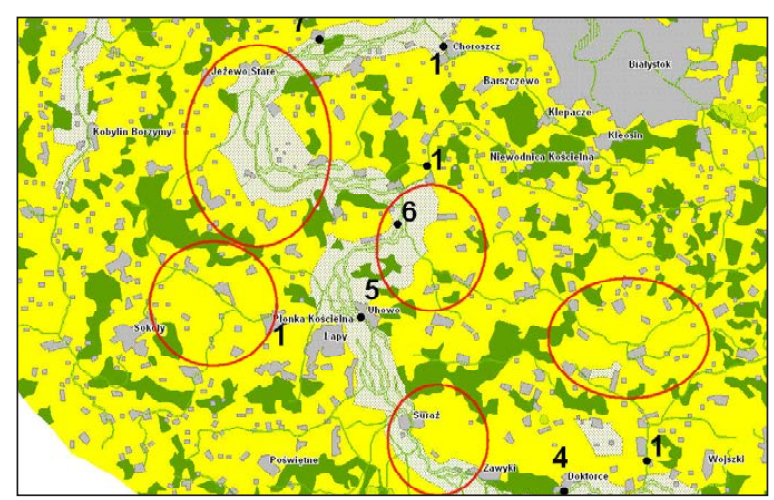

Figure 16. Localization of zones potentially threatened by biogens pollution, surface water from the fields and grasslands. $\longrightarrow$ - danger zone 


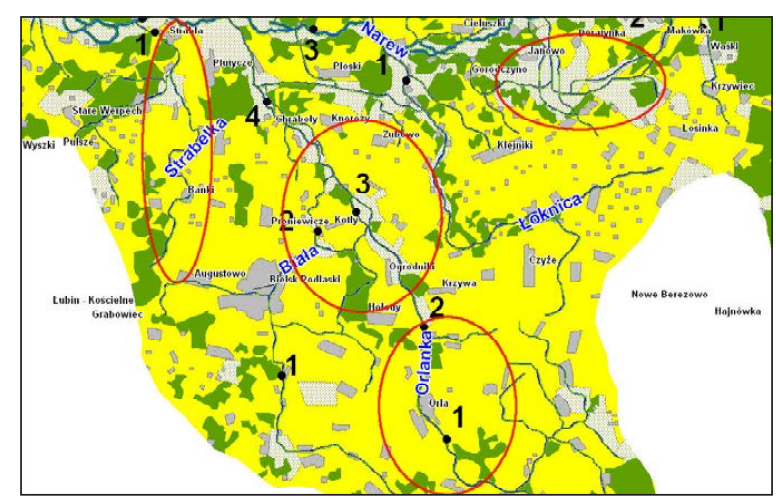

Figure 17. Localization of zones potentially threatened by biogens pollution, surface water from the fields and grasslands

$\longrightarrow$ - danger zone, yellow shape - fields, green dotted shape - grassland, green shape - forest

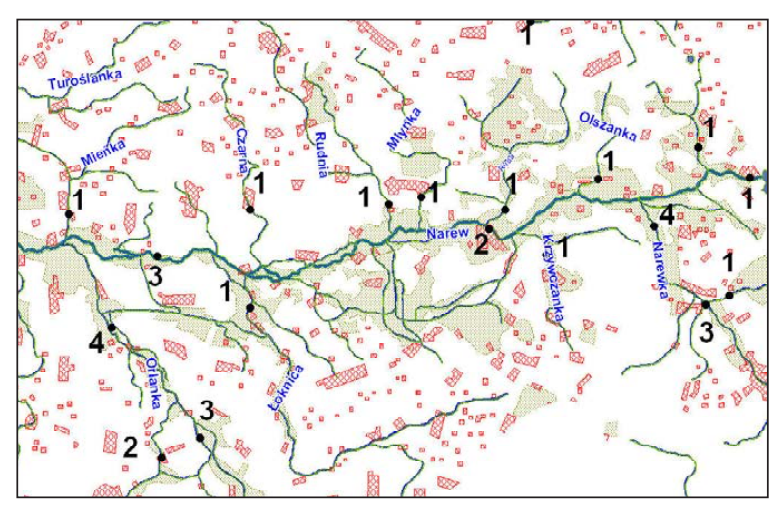

Figure 18. Range of grasslands along Narew river. Green dotted shape - grassland

Combining with the fields, they form summarized areas being an existing or potential risk for aqueous environment, which requires systematic monitoring and analysis.

\section{CONCLUSIONS}

1. The spatial analysis allowed to make modelszones of the existing and potential threat of pollution of waters in the Narew river catchment.

2. Designated danger zones can be verified by studies as well as can be very helpful in determining the monitoring network and during water quality modeling process.

3. GIS technique allowed to predict and forecast the localization of the site where contamination of both surface waters and other environmental components, can occur.

4. The software of GIS MapInfo class fulfilled its task in spite of some imperfections related

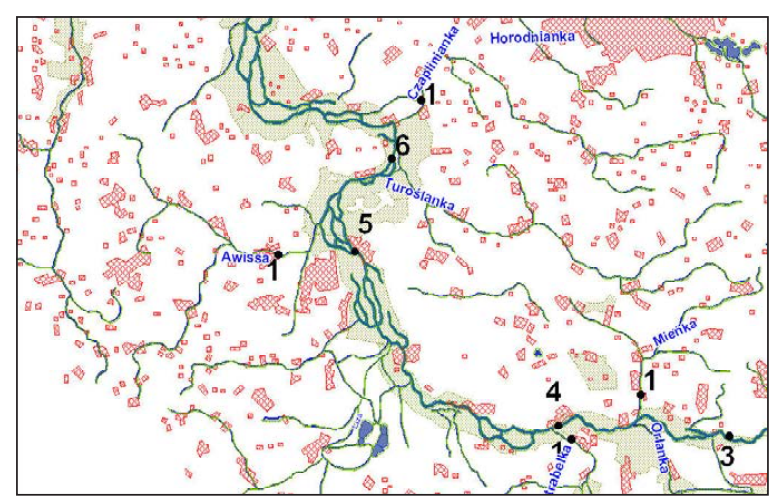

Figure 19. Range of grasslands along Narew river. Green dotted shape - grassland

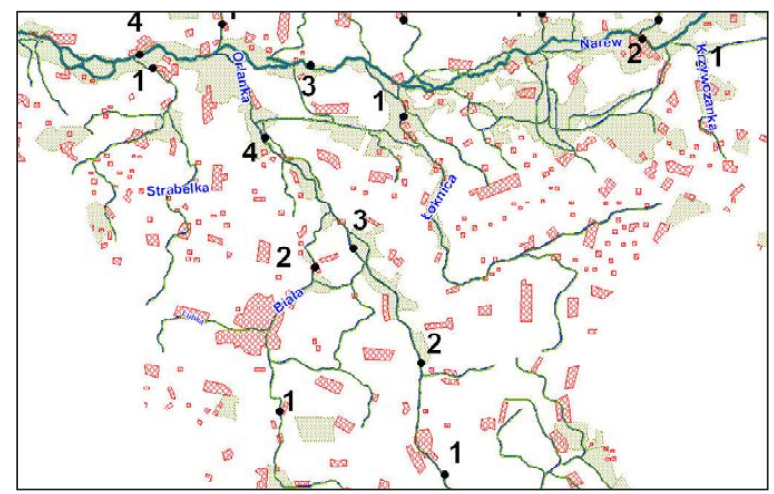

Figure 20. Range of grasslands along Narew river. Green dotted shape - grassland

to its version, which no longer belongs to the newest ones.

5. GIS modeling should be routinely used in studies and spatial modeling of larger areas, in particular river catchments.

\section{REFERENCES}

1. Gliński P., 2010. Wykorzystanie systemu informacji przestrzennej (SIP) do oceny lokalizacji lotniska w aglomeracji miejskiej, Teka Kom. Arch. Urb. Stud. Krajobr. - OL PAN, 210-220.

2. Helis M., Górecki A., 2013. Projektowanie zmian użytkowania $z$ uwzględnieniem potencjalnej erozji wodnej gleb i retencji krajobrazu na przykładzie mikrozlewni górskiej. Inżynieria Ekologiczna, 32, 48-54.

3. Izdebski W., 2008. Wykłady z przedmiotu SIT/ MAPA zasadnicza. Politechnika Warszawska.

4. Klimczak H., Galant K., 2009. Modelowanie kartograficzne w ochronie środowiska przyrodniczego. 
V Ogólnopolskie Sympozjum Geoinformacyjne „Geoinformatyka dla środowiska i społeczeństwa - badania i zastosowania”, Kraków.

5. Myrda G., 1997. GIS czyli mapa w komputerze, Helion.

6. Nowicka E., Olszewska B., Kopańczyk K., Klimczak H., Pływaczyk L., 2014. Ocena zmienności poziomu wód gruntowych z zastosowaniem gradientowego pola wektorowego. Inżynieria Ekologiczna, 39, 105-113.

7. Nowicka E., Dąbek P., Olszewska B., Żmuda R., 2015. Analiza przestrzennych zmian stanów retencji gruntowej doliny Odry w rejonie Malczyc. Inżynieria Ekologiczna, 44, 40-46.
8. Poławski Z., 1998. Modelowanie kartograficzne w GIS. Prace Instytutu Geodezji i Kartografii, tom XLV, zesz. 97.

9. Stabłoń E., Augustyn A., Ślusarek A., 2015. System geoinformacyjny do tworzenia map akustycznych dróg. Inżynieria Ekologiczna, 42, 72-77.

10. Urbański J., 2012. Gis w badaniach przyrodniczych. Domena Publiczna, ebook. ss 266.

11. Zemanek J., Malinowski M, Woźniak A., 2009. Opracowanie zasad wyboru lokalizacji „centrum recyclingu” z wykorzystaniem analizy wielokryterialnej GIS. Infrastruktura i Ekologia Terenów Wiejskich, Komisja Technicznej Infrastruktury Wsi, No. 5, 219-230. 